\title{
Draco's Constitution and Political Ideas of Athenian Oligarchs
}

\author{
Alexander Verlinsky \\ St. Petersburg State University, \\ 7-9, Universitetskaya nab., St. Petersburg, 199034, Russian Federation; a.verlinskij@spbu.ru
}

For citation: Alexander Verlinsky. Draco's Constitution and Political Ideas of Athenian Oligarchs. Philologia Classica 2021, 16 (2), 186-206. https://doi.org/10.21638/spbu20.2021.202

In the article which serves as a sequel to an earlier one the author argues that Draco's constitution (DC) in Arist. AP 4 does not derive from an oligarchic political pamphlet in which it served as a prototype of a constitution to be implemented in Athens as the majority of scholars believe. The preponderance of scholars believe, relying on the alleged similarity of DC to the project of the 'Constitution of Five Thousands' (AP 30) in $411 \mathrm{BC}$, that DC emerged in the same 'moderate' oligarchic circles as a project of the same kind. Others propose later dates for its appearance but almost unanimously ascribe to oligarchic moderates who pleaded for a 'hoplite constitution.' The author argues contra that although DC is not reliable as a historical document, it differs considerably from the known political projects of oligarchs. Its distinguishing features make it anachronistic for conditions of $5^{\text {th }}-4^{\text {th }}$ centuries $\mathrm{BC}$, but they are much more at home in the last decades of $7^{\text {th }}$ BC. It is likely that Aristotle found this fictional account in one of the historical sources he used in the AP in which it was fabricated to fill a gap in the lacunose history of the early Athenian constitution and it may have been meant to diminish tendentiously Solon's contribution, representing the latter as modifying the already existing state order.

Keywords: Aristotle, Draco's constitution, political ideas of Athenian oligarchs, historical sources of Arist. AP.

The constitution, which according to the fourth chapter of the Athenaion Politeia by Aristotle $^{1}$ (henceforth $A P$ ) was implemented by the famous legislator Draco (henceforth DC), became the subject of hot debates immediately after the publication of the papyrus text in 1891. Scholars discussed both the historicity of this constitutional order which is otherwise practically unknown to ancient tradition, and its authenticity as a part of the treatise's text. Both these questions were estimated as being settled by Georg Busolt in

${ }^{1}$ I do not hesitate to call the author of the AP Aristotle, which is not fashionable today, because I see no weighty argument to disprove Aristotle's authorship: some features of the AP style, its similarity of tendency and content to Aristotle's Politics (although there are some minor differences) and the indications of the time of the composition of the AP, between 330/29 and 322/1 BC (Antipater's constitution is not mentioned in the AP), favour Aristotle's authorship; in Verlinsky 2017, 148-150, I argue that there is no reason to suppose two editions of it as some scholars did, even less an edition after Aristotle's death. Collaboration with some students cannot be ruled out but there is no evidence for or against it; considerations about the bulk of the corps of constitutions and difficulties of its writing by Aristotle alone, plausible as they might be, do not help in determining Aristotle's particular contribution: it might have been considerable taking in account his extraordinary working habits (remember the total bulk of his treatises on natural sciences!) and of course, as some scholars noted the constitution of Athens was extraordinarily important for the whole project so as to call for his closer engagement.

(C) St. Petersburg State University, 2021 
the first volume of Griechische Staatskunde finished in 1914 but published in 1920: DC is a later addition to the text made either by Aristotle himself or by some redactor of his text. It was also agreed upon that it is non-historical because its provisions are for the most part anachronistic; rather it is a political pamphlet, an oligarchic program under the guise of a historical account. The majority of scholars believed that this pseudo-historical constitution was born among the moderate supporters of oligarchy during the revolution of $411 \mathrm{BC}$, in the so called 'Theramenes circle', due to some similarity of DC to the constitution of the 5,000; the minority ascribed it to the activity of the same group in $404 \mathrm{BC}^{2}$

In a paper published some years ago, ${ }^{3}$ I tried to challenge the first half of this opinio communis, and argued that there are no weighty reasons to treat Draco's Constitution as the interpolation and even as the later addition to the text made by the author himself. The omission of number with Draco's constitution in the list of constitutional changes in chapter 41 , which was usually regarded as the main evidence in favour of an interpolation, does not show that it does not figure as a constitutional change: rather the first change under Ion, the introduction of the tribal order, was not regarded as constitutional. In this work, I will try to challenge another half of the prevailing view, namely that DC stems from an oligarchic pamphlet, in which it served as a prototype of the constitution to be implemented in Athens. Here is the text of this remarkable account (AP 4): ${ }^{4}$

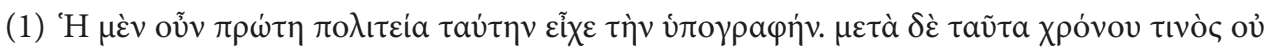

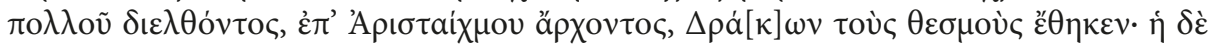

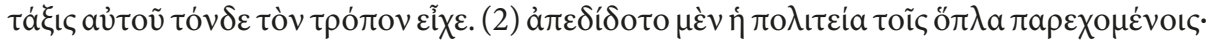

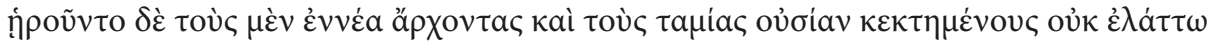

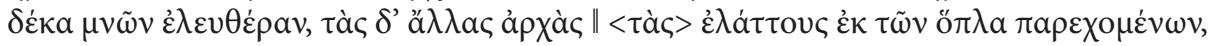

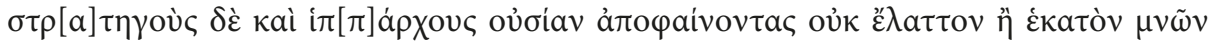

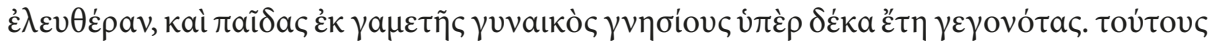

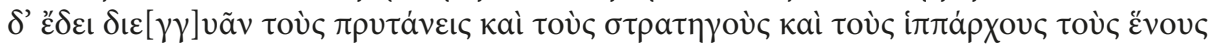

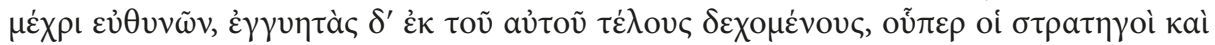

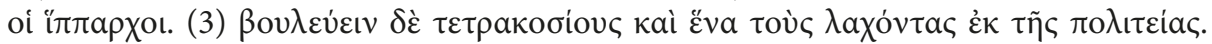

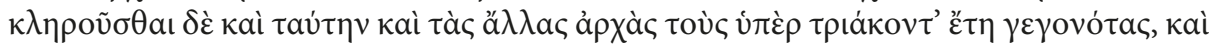

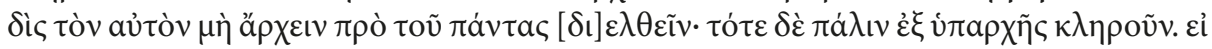

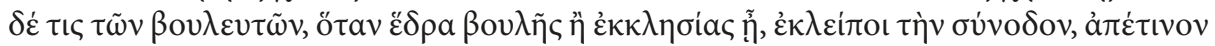

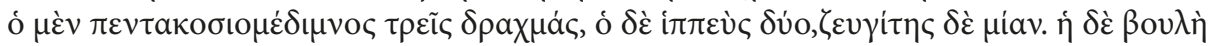

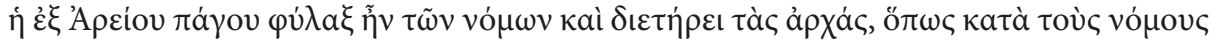

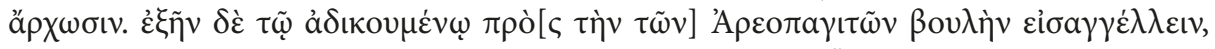

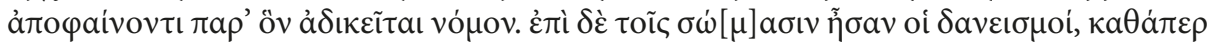

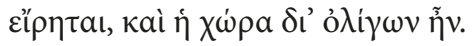

(1) That is the outline of the first constitution. When not much time had passed after this, in the archonship of Aristaechmus, Draco enacted his statutes. The structure of his constitution had the following form.

(2) Political rights had been given to those who provided arms. They elected the nine archons and the treasurers, men owning unencumbered property worth not less than ten

2 Busolt (- Swoboda) I, 1920, 52-58; II, 1926, 577 (Swoboda's addenda). Few scholars tried to defend the historicity of DC after that: Rizzo 1963; Cataudella, 1966, 183-193; Develin, 1984; against Rizzo see, briefly, Hammond 1966; against Develin see Wallace 1992. For the details of the status quaestionis, see Verlinsky, 2017, 142-147.

3 Verlinsky 2017.

${ }^{4}$ Henceforth the text of the AP is cited according to Chambers 1994. 
minas, and the other, lesser, officials from those providing arms; and as generals and hipparchs men declaring unencumbered property worth not less than a hundred minas, with legitimate children over ten years old by a wedded wife. These (i. e., the acting generals and hipparchs) should be held to bail until their euthynai by the prytanes, the generals and the hipparchs of the previous year, who accept as guarantors for each 4 men of the same financial class as the generals and hipparchs. (3) The council comprised four hundred and one men appointed by sortition from those with political rights. This appointed by lot to the other offices men over thirty years old, and the same man could not hold an office for a second time until all had gone through; then they made allotments again from the beginning. If any of the councillors, when there was a session of the council or assembly, missed the meeting, a pentakosiomedimnos had to pay three drachmae, a hippeus two and a zeugites one. (4) The council of the Areopagus was guardian of the laws, and it kept watch over the officials to see that they conducted their office in accordance with the laws. It was possible for a man who was wronged to make an eisangelia to the council of the Areopagites, indicating the law in contravention of which he was wronged. (5) Loans were on the security of the person, as has been said, and the land was in the hands of a few (Tr. by P. J. Rhodes, 2017, modified).

The main portion of arguments against the authenticity of DC are based on the anachronistic character of its provisions. To avoid any misunderstanding, I will state in the very beginning that I find the arguments in general cogent, although some of them are of course more, others less, convincing because we are not in a position to determine in every case at what date this or that institution was introduced. ${ }^{5}$ I will return to some of these arguments in due course to illustrate that the institutions definitely rejected as non-historical nowadays were not obvious anachronisms in the time of Aristotle, and even not for the scholars of 1890s who wrote soon after the discovery of the AP. ${ }^{6}$

Some more general points can be added to the arguments against the authenticity of single provisions: DC is more detailed than the account of the Solonian constitution (not speaking of the very lacunose account of the 'ancient' constitution in ch. 1-3). This detailed character is suspicious: even if Draco in fact issued laws on constitutional matters, they certainly could not have had the form of a full-blown constitution. ${ }^{7}$ Scholars in general agree that a systematic description of constitutional order is improbable for the earliest law-codes. ${ }^{8}$ The detailed description of a constitution could be only based on sin-

5 The earliest arguments against historicity are dispersed in the papers which appeared immediately after publication of the London papyrus, cited in Verlinsky 2017, n. 3; more detailed and taking into account the earlier work are Meyer, 1892, I, 234-236; Busolt, 1895, 36-41; Busolt, I, 1920, 55-57; Ledl, 1914.

${ }^{6}$ It is useful to recall that Busolt gradually changed his attitude from defending DC as a real historical document in 1891 via a hypothesis, that Aristotle collected the material for from the Atthides later also in 1891, to rejecting DC on the whole as a fraud in 1895; in 1920 he also endorsed the view of it as a later insertion of the text (see Chambers, 1990a, 101). Other distinguished scholars remained stubborn defenders of historicity in the debates of 1891, including Wilamowitz who was not convinced by the arguments contra of Meyer and Busolt. See further, against Meyer, in favour of historicity, Seeck, 1904.

7 According to $A P$ 7.1, all Draco's laws were abandoned except those on homicide after Solon's laws had been enforced. The historicity of the other laws beyond homicide and their accessibility in $5^{\text {th }}-4^{\text {th }}$ centuries BC were debated: see in favour of existence and preservation of such laws Stroud, 1968, 75-83, Sickinger, 1999, 200 n. 21; 202 n. 50; Carey, 2013, 38-42; Gagarin, 2008, 93 believes that both are possible. Rhodes, 1981/1993, 111 thought that the other laws existed, but doubted (p. 131) that they were preserved; Leão - Rhodes, 2016, 3, 12, leave open the question whether any other laws of Draco ever existed.

${ }^{8}$ Regarding this, Hansen, 1989, 83-85 argues that constitutional matters were regulated in Solon's time for the most part by 'tradition and by rules that were orally transmitted' (p. 84) and disbelieves ac- 
gle laws unified by some person in the $5^{\text {th }}-4^{\text {th }}$ centuries $\mathrm{BC}$, and thus it is only possible to consider the historical reliability of each provision separately. ${ }^{9}$

The other judgment on DC which played an important role in the 1890s and remains practically indisputable up to the present day, among those who deny its authenticity, was that DC is an oligarchic forgery concocted in the revolutionary months of 411-410 BC by Athenian oligarchs who hoped to provide a fictional historical support for its plans, trying to show that they would bring the state back to the pre-Solonian political order - since Solon in their view laid the foundations of democracy. Proponents of this opinion referred to the similarity of DC to the project of 'constitution for future' or the constitution of the 5,000 as reported in the AP 30. This later constitution was regarded by many scholars as a project which arose in the circles of Athenian moderate oligarchs, Theramenes and people of the same mood, in contrast to the project in the AP 31, the narrow oligarchy of 400 , that was associated with radicals which was in fact implemented in $411 .{ }^{10}$

This proposal won overwhelming support in scholarship, although the differences between DC and the Constitution of the 5,000 were noticed already by Ledl, 1912, 27, 30 . He ascribed DC to more moderate oligarchs than the group that drafted the constitution of the 5,000. Cloché, 1940, argued that they are different, however, they both reflect equally moderate views - some liberal features of DC are counterbalanced by liberal aspects of the Constitution of the 5,000.

Not all scholars accepted the arguments of Meyer, Busolt and others against the historicity of DC. Nevertheless, even those who pleaded for authenticity were impressed by the similarity of DC to the Constitution of the 5,000. This similarity was for Wilamowitz so striking that he posited the dilemma (I, 76) - either oligarchs followed the real constitution of Draco or they forged it as a pseudo-historical justification of their own constitution. Wilamowitz himself pleaded for the former horn of the dilemma and argued that some learned oligarch of the circle of Antiphon and Theramenes compiled the text later used in the $A P$ from the single provisions he found in Draco's inscribed laws (Wilamowitz I, 77, 98).

However, in 1951 Alexander Fuks challenged the view that DC should be necessarily related to the oligarchic revolution of 411 or $404 / 3 \mathrm{BC} .{ }^{11} \mathrm{He}$ assumed that DC is

cordingly that there was authentic knowledge of Solon's constitutional reforms in $4^{\text {th }} \mathrm{BC}$, and Rhodes, 2006, 251, who admits that some limited knowledge based on Solon's constitutional laws was accessible. The laws on the election of officials and some other constitutional provisions are attested for in the $7^{\text {th }}-6^{\text {th }}$ centuries BC (Dreros, Gortyna, Chios), see Gagarin, 2008, 56, 58, 76, 81. It is thus quite possible that some of Solon's constitutional laws mentioned in the AP and beyond date back to the laws inscribed on axons; Hansen's skepticism is thus excessive. Ruschenbusch, 1966, 26 points to some constitutional regulations in Solon's laws but argues convincingly that there was no Verfassungsgrundgesetz of the type of DC (cf. Hölkeskamp, $1999,262-64$ on the lack of unity in earlier law codes).

9 At the same time, we cannot rule out the idea that ascribing a major constitutional reform to Draco is somehow related to his preserved law on homicide. Thus Pollux 8. 125 claims that Draco established the collegium of fifty-one ephetai who were to hear prosecutions for homicide (Wallace, 1989, 13f.). This claim is certainly based on the text of Draco's law on homicide which mentions fifty one, the ephetai and the procedure of their election (cf. Wallace, $234 \mathrm{n}$. 64). The thought itself that Draco was an author of the constitution may have arose from the tradition that Solon replaced all of Draco's laws but one on homicide with his own laws - it was thus possible to speculate that among those abandoned were constitutional laws.

10 This view was brought forward by Headlam 1891, 166-168, and simultaneously by some other scholars. Others supposed that DC was forged by Theramenes and his supporters during the later coup detat of 404/3 (see Verlinsky 2017, 143 note 3 for further references)

${ }^{11}$ Fuks, 1953, 84-101. 
non-historical (p. 84) and that it was an addition to the main text (p. 96 f.). He pointed out considerable differences between DC and the constitution of the 5,000 ('constitution for the future'), according to the AP 30 (and 29.5 which Fuks takes to be a part of the same project, in spite of some differences), which he considers to be identical with the constitutional plan of Theramenes' group that was realized after the fall of the regime of 400. His own view is that in spite of considerable differences between both constitutions in technical organization of the citizen body, their basic principles are identical (foremost, the restriction of citizenship to the hoplites). He agreed that the general principles of DC and the Constitution of the 5,000 are similar - the restriction of citizenship to those who have the hoplite status, the abolition of payment for membership in the Council, explicitly in the Constitution of the 5,000, implicitly in DC, and the principle of full rotation of the Council's members; they are chosen by lot until the whole citizen body is exhausted (in the Constitution of the 5,000 it occurs every four years). There are some lesser similarities and also considerable differences between the two constitutions, mainly in organization of the Council.

Nevertheless, the differences, according to Fuks, do not imply a more or less oligarchic group than that of Theramenes - both constitutions belong with the moderate group as opposed to such people as Antiphon or Peisandros in 411 BC or Critias in 404, who pleaded for a limited citizen body, but in reality aimed for extreme narrow rule, a dictatorship of a group that initiated the revolution. However, Fuks denied that DC was a forgery which arose in the circle of Theramenes: first, because he found it unbelievable that some members of the moderate group propagated their views under the slogan of returning to the constitutions of Solon and Clisthenes, while others at the same time and practically with the same goals to the invented constitution of Draco. Second, he noticed that some provisions of DC were reminiscent of those which are not attested for earlier than in the fourth century BC, such as qualification for the office of strategos - he should have sons born in lawful marriage, which is attested in one passage of Dinarchus - or bailing by the members of the same property class, attested in Demosthenes $24.144 .{ }^{12}$ For these reasons, he supposed the idea that DC belongs to a moderate oligarchic group from the $4^{\text {th }}$ century and originates from a pamphlet such as Isocrates' Areopagiticus: 'such a pamphlet is to be regarded as an invention, going perhaps into more 'historical' detail than the Areopagitikos, but hardly as the rather sinister 'forgery' concocted for immediate political use which 'Drakon's constitution' is commonly supposed to be' (p. 96).

Fuks' general view that DC is tendentious interpretation of Athenian constitutional history rather than a disguised political project is in fact plausible, and it had some effect on scholarship as well as his dating of DC to the fourth century. He was also able to point out the differences between DC and the constitution of the 5,000. Nevertheless, Fuks' arguments against the appearance of DC in the course of political struggle approximately $411 \mathrm{BC}$ are not entirely convincing. Our evidence for the period is not so exhaustive that we could definitely rule out the existence of an oligarchic group which could agitate for its constitutional vision using the name of Draco. ${ }^{13}$ Also, observations on the similarity of

12 Fuks, 1953, 95 f.

13 For instance, the laws of Clisthenes are mentioned only once in our sources in connection with the events of $411 \mathrm{BC}$ - in the amendment proposed by Clitophon to the phephisma of Pythodorus at the assembly which abolished the democratic constitution (AP 29, 3): this amendment recommended syggrapheis who were elected to change the constitution and 'the ancestral laws of Clisthenes which he established when 
some provisions with those attested in the $4^{\text {th }}$ century are suggestive but not necessarily cogent: it can only be due to chance that such provisions are not attested for in the fifth century.

Again, Fuks' analogy, Isocrates' Areopagiticus, does not help to understand the purpose of the treatise which might contain DC: Isocrates, it is true, not only proposes a politically coloured interpretation of history; he also pleads for certain constitutional changes of the Athenian political order which correspond to the good old time: the abolition of the selection of officials by lot and introducing instead their election from the wealthy class by vote (7.21-27), and giving the Areopagus the right of moral control over the citizen body (most of all, over the officials). ${ }^{14}$ We do not know what kind of political reaction (if any) Isocrates expected from this part of his speech beyond regret that the state deteriorated, but certainly his objection is not a political reform. DC, with its very precise, even if not comprehensive, character appears differently: it consists of particular provisions on enfranchisement, modes of election and sortition of members for the assembly, the council, and the officials; on the census, on the bail of higher officials, on fines for non-attendance at the assembly and the council, etc. If it is simply an oligarchically coloured pamphlet without any idea of implementing such a constitution, then what was the purpose of these very precise constitutional provisions?

Fuks' argumentation had some effect since certain scholars after him preferred to treat DC as stemming from a tendentious but pseudo-historical, rather than political, treatise, from the fourth century BC. ${ }^{15}$ However, other scholars either finding Fuks' arguments insufficient or simply ignoring them maintained, as earlier, the influence of the moderates' political ideas of $411 \mathrm{BC}$ (the impact of this hypothesis is also experienced in the views of those who treat $\mathrm{DC}$ as speculative historical reconstruction). ${ }^{16}$ The theory of DC as a political project in the guise of a historical account was recently recovered by H. van Wees who argued that ideas were interpolated in the text of DC by Demetrius of Phalerum, to serve as a pseudo-historical precedent for his own oligarchic constitution. ${ }^{17}$

founding democracy.' The amendment of Clitophon, who was associated with Theramenes, almost certainly represented the views of moderate oligarchs (see Fuks, 1953, 1-32; Heftner, 2001, 130-141).

14 Wallace, 1989, 164 f.: according to Wallace, Isocrates also earlier held the view 'that the best government is that in which the best men lead, and such a government may exist under any constitution', and he 'praises democracy before or at the time of the Persian wars' (p. 162). Nevertheless, only in the Areopagiticus written in 358 or $357 \mathrm{BC}$, shortly before the beginning of the Social War, Isocrates pleads for constitutional reform.

15 Ruschenbusch, 1958, $421 \mathrm{f} .:$ the author of this anachronistic but historically conceived account was Demetrius of Phalerum (this modifies the earlier suggestions of Jacoby 1949, 94; $385 \mathrm{n} .1$ that the forgery of the oligarchs from the end of the fifth century BC entered the AP via Demetrius' On the Athenian Constitutions); Rhodes, 1981/1993, 86 (chs. 3 and 4 of the $A P$ 'both represent theoretical reconstruction rather than well-documented history'), but cf. p. 368: DC is a part of 'polemical writing' born by political struggle at the end of the fifth century; Wallace, 1992, 270: DC was fabricated in the second half of the fourth century BC as part of moderate oligarchic ideology, the part of which was Isocrates' Areopagiticus; the author was a historian; Poddighe 2014, 143: DC was compiled as an attempt to reconstruct the earliest phase of Athenian constitutional history by Aristotle himself, who in lack of authentic material combined in it the elements typical for the 'hoplite constitution', which were likely discussed during oligarchic revolutions of the fifth century.

16 Thus Cecchin, 1969, 93-101. Figueira, 1992, 295-301 following K. von Fritz treats DC as an integral part of the AP (p. 297) and notices historical anachronisms (p. 295), supposes that DC originated in the moderate oligarchic circles after defeat in Sicily $415 \mathrm{BC}$, but he does not relate it directly to the projects of 411. His arguments in favour of the $5^{\text {th }}$ century date are not convincing.

17 Van Wees, 2011. 
Since we are still wandering in the field of pure hypotheses, it is time to reconsider the relation of DC to the projects of oligarchs from the fifth - fourth centuries BC.

Citizen rights in DC are granted to those who are able to provide the hoplite equipment (4.1). From the beginning of discussions on DC, this provision was the most striking point of similarity with the constitutional plans of 'moderates' because the scholars believed that Theramenes' and his group's purpose in 411-410 BC was the enfranchisement of all people to the hoplite status (Fuks, 1953, 87).

However, nowadays there are solid grounds to doubt this similarity. The decision of the assembly in Colon, which instated the oligarchic regime, was to elect 5,000 to rule over Athens through the end of the war (Thuc. 8.67. 3; AP 29.5, cf.). Both Thucydides and the $A P$ point out that the requirement for enfranchisement was not hoplite service by itself, but the special ability of serving the state by 'bodies and property.' ${ }^{18}$ The number of persons who served as hoplites was certainly about twice more than 5,000. ${ }^{19}$ The constitutional project for the future drafted by the collegium of syggrapheis and approved by the Athenian people soon after this envisaged the rule of just 5,000. Nevertheless, the real power ended up in the hands of the council of 400, according to the interim constitution. This narrow oligarchy soon found itself in a clash with the Athenian fleet on Samos, and under the pressure of democratic forces on Samos and combined resistance from moderates and democrats in Athens themselves, was overthrown by the uprising of Athenian hoplites. After the fall of the regime of 400 the power passed to the 5,000 according to the AP 33.1. ${ }^{20}$ However Thucydides (8. 97. 1), although also saying that the people voted for granting power to the 5,000, adds that in addition they voted that all those who belong to hoplites should now partake in government. ${ }^{21}$ This statement, albeit a bit awkward, ap-

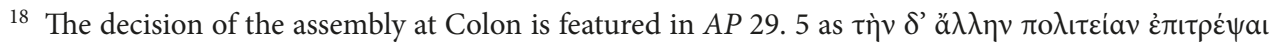

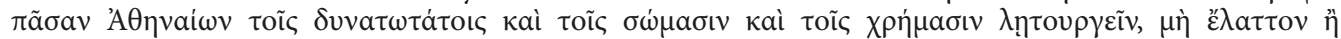

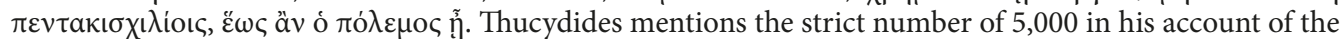
assembly decision, which probably reflects the fact that only 5,000 citizens were selected after that.

19 The exact number of hoplites at this time cannot be defined: but even the most cautious scholars do not doubt that it was much more than 5,000, see (Gomme) - Andrewes, 1981, 329; Rhodes, 1981/1993, 383 f. According to [Lys.] 20.13, Polystratus, one of hundred katalogeis, put 9,000 future citizens on the list instead of 5,000 according to the new constitutional order. Some scholars believe that 9,000 is the total number of hoplites, whereas the oligarchs planned to enfranchise 1,000 cavalry men and 4,000 hoplites (Németh, 2006, 50 f.; he assumes that cavalry men had to be enfranchised completely and were not catalogised, but it is quite possible granted that we do not know the real procedure that the cavalry men were listed too); Ferguson, 1927, 338 and after him, Gomme, 1933, 7, relied on the same evidence but supposed that 9,000 was only a part of hoplites, those 30 years and older (because 30 was the minimal age for citizenship, see AP 30.2; Ferguson assumed, without sufficient grounds, that this restriction was in force when 5,000 came to power, but he might have been right that Polystratus made the catalogue under this restriction). However Heftner, 2011, 142 f., points out that it is quite possible that Polystratus also put those on the list who were below the hoplite class because the point of the oration is his democratic feelings and desire to serve the members of his deme (Heftner believes, nevertheless, that the number of the hoplites beyond the numerus clausus of 5,000 was considerable, including those under the age of 30 and those who did not want to partake in the new order, cf. Heftner, 2001, 152 n. 176 - more than 9,000). But in fact (see the previous note), the official qualification was rather vague and did not correspond to any class divisions; it allowed for the exclusion of members of the hoplite class according to the will of katalogeis. Polystratus certainly could not alone select 9,000 enfranchised (Heftner, 2001, $150 \mathrm{f}$., reasonably supposes that the expanded quantity was the result of activity of the whole body or at least many of its members).

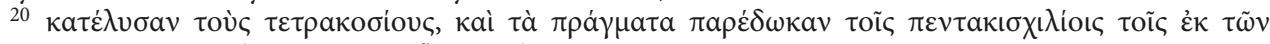
ö $\pi \lambda \omega v, \psi \eta \varphi$ เ

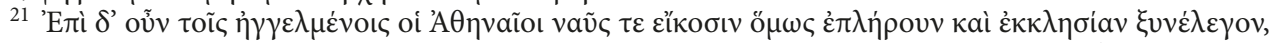

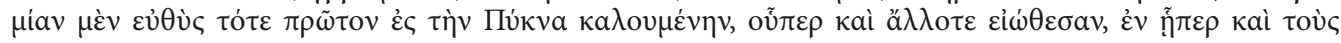


pears to be correct and probably means that the 5,000 who were already on the list of the enfranchised should be the indispensable part of this new order, and the people not listed but with hoplite status should be added to them.

It is clear that DC is different from the project of 'the constitution for the future' in several important aspects: the latter is founded on the layer of the 5,000 enfranchised which is narrower than the whole body of hoplites. Moreover, there are some other important differences - it abandons the assembly substituting it with the council of 400 consisting of four parts who rule in turn, contrary to DC where both council and assembly function.

Nevertheless, some scholars believed that DC is similar to the constitutional projects of the oligarchs because they insisted that the political order which was instituted in $410 \mathrm{BC}$ after the overthrow of the 400, founded on the enfranchisement of all those who served as hoplites, was a realization of Theramenes' and the moderates' plan. ${ }^{22}$ Fuks who endorsed this view based it on several assumptions: 1) it appears that the 'moderates' from the beginning of the revolution pleaded for the number of the enfranchised to be greater than 5,000 ; 2) Theramenes during the later oligarchic revolution of 404/3 BC defended again the 'hoplite' constitution, viz. the enfranchisement of all hoplites; 3 ) the 'constitution of the future' of the AP 30 (and also the decree of the assembly which instituted the power of 'the non less than 5,000 citizens' according to the AP 29.5) corresponded to the views of Theramenes and his group.

Now Xenophon, Hell. 2.3. 48, our only evidence for the program of Theramenes, ascribes to him in the alleged speech held by Theramenes in his defense in 404/3 BC the statement that both in the past (viz., presumably during the events of 411-410 BC) and in the present (404/3), he supported the constitution in which the power is in the hands of those who can serve the state 'with horses and shields', which corresponds to the 'hoplite constitution.' It is not clear whether these words are based on Xenophon's knowledge of Theramenes' written defense of this ideal or only on his role in the overthrow of the 400 and the institution of the hoplite state, but it is clear that they are not based on the project of 'the constitution for the future' with its more narrower citizen base of 5,000 cavalry men and hoplites.

Equally, there is no conclusive evidence that Theramenes and the moderates tried to expand the quantity of the enfranchised beyond 5,000 in 411-410 BC. ${ }^{23}$ 'The constitution

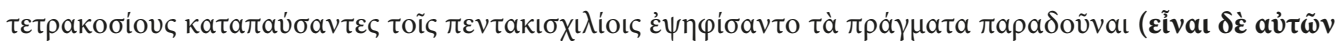

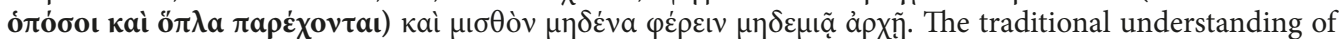
the parenthetic sentence, 'to them $(5,000)$ should belong also those who provide the hoplite equipment', seems to be correct. The alternative interpretation proposed by V. Ramon in Sancho Rocher, 1994, 51, '(and it has been voted that they, viz. the 5,000) should be from the number of those who provide the hoplite equipment', has some advantages (it removes the contradiction with the AP and also the awkwardness that

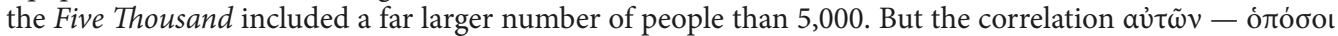
is harsh (I did not find relevant examples of it in Thucydides). Moreover, if 5,000 were already selected, as appears to be the case, the assembly would not have voted on who should belong to the 5,000: the parenthetic clause thus should contain some new provision. Against the new proposal, see Heftner, 2001, 279 note 1, with somewhat different arguments.

22 Thus, for instance, Busolt - Swoboda, I, 1920, 55 and many others before and after.

${ }^{23}$ Fuks' hypothesis of the broader citizen body defended by the moderates is based on the notice in AP 29.5 that the decree of the Colon assembly assigned political rights to those who were the most able 'to serve the state with their bodies and money in the number not fewer than 5,000', contrary to the slogan of the radical oligarchs' propaganda at the beginning of the coup détat, 'not more than 5,000', according to

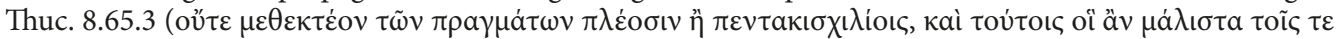

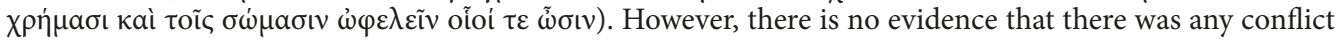


for the future, which was approved by the people later than the list of the 5,000 enfranchised had been compiled, still preserved the same restricted number. We can of course imagine the situation where Theramenes drafted 'the project for the future' under the pressure of more radical oligarchs. But also afterwards, when the attested clash of Theramenes and his supporters with the radicals had started, Thucydides represents the former as defending the rule of 5,000 citizens, viz. the provision of the Colon decree (see 8.89.2; 92.11; 93.2; Thucydides shows no awareness of the drafted project of 'the constitution for future'). At the end, when the 'hoplite constitution' was in reality implemented after the overthrow of the 400 , it appears different from this project not only in respect to the much broader citizen body but also in some other important aspects. ${ }^{24}$ This 'hoplite constitution' which existed in $410 \mathrm{BC}$ does not correspond to some known written project. It may have been only the natural result of the defeat of the oligarchs by the Athenian hoplites, who included two earlier conflicting groups, moderates and democrats, who were now jointly opposed to a narrow oligarchy of 400 . Evidence for the 'moderates' as proponents of 'the hoplite constitution' in 411-10 BC is thus meager if it exists at all; equally, there are no convincing reasons to treat 'the constitution for the future' as being the same as 'the hoplite constitution' as it was enforced in $410 \mathrm{BC}$. The enfranchisement of the hoplites in accordance with the DC thus can be compared only with the latter order of state, whose details are not known and which was probably not projected before its installment.

The 'hoplite constitution', namely the enfranchisement of all those who struggled in heavy armor, was probably not in the cards even for moderate oligarchs in $411 \mathrm{BC}$, because the whole body of hoplites (or even the majority of it) in the last decades of the $5^{\text {th }}$ century BC did not already belong to the well-propertied 'middle' class, which was regarded as an appropriate social base for a state that moderates tried to establish. ${ }^{25} \mathrm{An}$ -

among the oligarchs about the number of citizens, and the formula of the decree may have only made the enforcing of the new order more attractive to the stratum of the Athenians; the number of those who were put on the list by the katalogeis was still 5,000, not more (AP 30.1). (Gomme) - Andrewes, 1981, 218, ad loc. supposes that the slogan 'not more than 5000' was later modified in favor of a more moderate 'not fewer than 5,000', according to AP 29.5; this might have been in fact the case, but in light of the striking similarity of expressions Thucydides uses for the formula of the decree according to AP 29.5 (cited above note 19), Thucydides' formulation can simply be the back projection of the psephisma's text, which he does not cite, on the

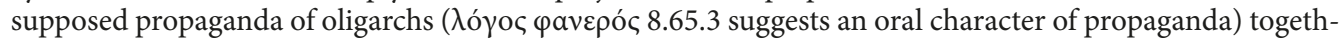
er with his knowledge that in fact more than 5,000 were not envisaged, in spite of the psephisma. There is no evidence that Theramenes and his supporters pleaded for the enfranchisement of a number greater than 5,000 also after the Colon assembly. Fuks refers (p. 87) to the case of Polystratus, who was a member of the 400 and a cataloguer - he put 9,000 names on the list of citizens ([Lys]. 20.13), which confirms in his view the words 'not fewer' of AP 29.5 as the object of the moderates. But it is quite possible that Polystratus in fact, as the author of the speech points out, attempted only to show his benevolence to the members of his deme (see above note 20), without any hope that the citizens list would be broader than 5,000 . Notice also that 'the constitution for the future' - according to the order of the events in $A P$, drafted later than the list of citizens was compiled - envisaged only 5,000 enfranchised, even after the end of the war, thus leaving no hope for 'the hoplite constitution' even in an indefinite future.

${ }^{24}$ The majority of scholars now rightly doubt that the new order functioned on the basis of the earlier drafted constitution 'for the future'; on the differences between them, see Rhodes, 1981/1993, 412. Heftner, 2001, $309 \mathrm{f}$., points out that according to Thuc. 8.97.1, the new constitutional order was the product of the nomothetai and of legislative activity of the assembly; but he admits nevertheless that some provisions of 'the constitution for the future' could be implemented in this time (p. 311); but although there is some indirect evidence that, beyond the limited number of citizens with political rights, some other remnants of oligarchic order were still in force at this time (the council was probably elected, not sorted by lot), there is no evidence of specific institutions of 'the constitution for future'.

${ }^{25}$ See Heftner, 2003, 14 note 41 (with further literature on the question). 
other reason was possibly that the leaders of oligarchs, both radical and moderate, who controlled the process of selection wished to decide ultimately on the composition of the citizen body in terms of not only property but also loyalty of the enfranchised; for this reason they should have been selected by the katalogeis without any strict property criteria

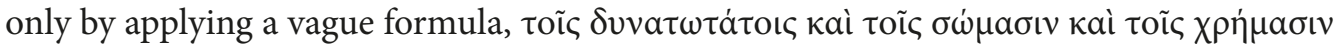

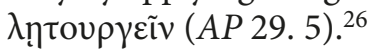

The citizen body under the oligarchy of Thirty was even more limited and more distant from the 'hoplite constitution' than that of the Five Thousand. ${ }^{27}$

The status of the enfranchised under the constitution of Antipater (322/1 BC), as well as under the less restricted constitution of Demetrius of Phalerum, is not traditionally called 'hoplite.' In the past, some scholars have identified the required level of wealth in the former (2,000 drachmas) with service as hoplites (some even supposed the influence of Aristotle's political theory on Antipater), but it has recently been rejected on good grounds: the citizen body under Antipater apparently did not include all those who served as hoplites. ${ }^{28}$ The more moderate constitution of Demetrius of Phalerum was based on the property census twice lower than that under Antipater (1,000 drachmas, according to the traditional interpretation), and the number of citizens under Demetrius was 21,000 male persons. ${ }^{29}$ This state order was recently interpreted as 'hoplite' by H.van Wees (he claimed that it is very similar to DC, which van Wees believes was forged by Demetrius to create a 'historical' precedent for his own constitution). The proposal on the 'hoplite' character of Demetrius' constitution does not carry conviction (on improbability of Demetrius' authorship of DC see Verlinsky 2017, 151); but even if it is correct, it implies that the hoplites thus enfranchised included a large portion of a class lower than the 'middle' class of independent landowners, a far cry from the ideal of Aristotle and of the oligarchs of the fifth century BC - and even more distant from DC, which completely excluded thetes from political rights. ${ }^{30}$

The reasons why service in the heavy infantry was not directly related to the 'middling' social and political class that appealed to the moderate oligarchs were in all probability different in the last decades of the fourth century BC from those of $411 \mathrm{BC}$. Nevertheless, it appears that also in this time the category of people who served as hoplites

${ }^{26}$ Cf. Hurni, 1991, 224; Németh, 2006, 50 f.

27 The constitution under the Thirty was officially a narrower oligarchy (3,000 citizens) than that of the constitutional project of the 5,000 in 411/10 BC, even more narrower than the hoplite constitution that was enforced in 410 BC, see Busolt - Swoboda II, 1926, 914 (see ibid., n. 6 for evidence); Németh, 2006, 20 f.; 53-60; the 3,000 played in reality no role in the rule of the state.

28 The treatment of Antipater's constitution as 'hoplite' goes back to Sundwall, 1907; it was endorsed by a number of scholars afterward; for those against it, see Poddighe, 2002, 109-140. The relation of enfranchised and disfranchised (9,000: 22,000), according to Diod. 18.18.4, appears to be more reliable than the 12,000 of Plut. Phoc. 28. 4 (see Gomme, 1933, 18), even if Diodorus' account is not quite accurate in all details. The enfranchised thus cannot correspond to the hoplites, whose number during the Lamian war should be 14,000-15,000, according to Gomme, 8 (van Wees, 2011, 99 counts 13,500 who could serve as hoplites without state funding).

${ }^{29}$ For the census, see Diod. 18.74 .3 and for the number of citizens, see Athen. 6. 272 c.

30 Van Wees, 2011, 97-100. Van Wees' argument that Demetrius' constitution was a 'hoplite' one depends heavily on the following claims: 1) that it was similar to DC, which is a circulus vitiousus; 2) that 1,000 drachmas was not the census threshold for citizen rights, but the census requirement for the highest offices, about which see below; 3 ) that the number of citizens, 20,000, included all hoplites, i. e., along with 13,000 who could equip themselves about 6,500 'poor' hoplites funded by the state. However, there is no warrant for the latter number, and thus there is no evidence that the criterion of hoplite service was involved. 
was not economically and socially monolithic and was not appropriate for defining the 'middle' stratum. ${ }^{31}$

It should be noted that, contrary to the often-expressed view, 'the hoplite constitution' is poorly attested for the $5^{\text {th }}-4^{\text {th }}$ centuries BC. Aristotle's judgment of the extraordinary rarity of this political order (Pol. IV.11. 1296 a 22-1296 b 1) in this time is confirmed by our current state of knowledge. ${ }^{32}$ On the other hand, Aristotle treats the hoplite constitution as a universal intermediate stage (or at least as one that had often occurred) between the oligarchic domination of the cavalry class and the democracy of the remote past (Pol. IV. 13. 1297b, 16-28), that is in the $7^{\text {th }}-6^{\text {th }}$ centuries BC. The reliability of this pattern of development, as well as Aristotle's identification of hoplites with the middle-propertied class, is nowadays an object of hot discussion, ${ }^{33}$ but need not worry us here. It is important that in Aristotle's time the hoplite constitution could be more readily associated with the age of Draco and Solon than with the contemporary age.

The next peculiar feature is that DC requires not only hoplite property for all enfranchised, but additionally the higher property qualifications for the highest officials. Further, there is gradation in fines for missing the sessions of the council and of the assembly, for the members of three property classes. ${ }^{34}$ These features prevent us from assigning DC to the $5^{\text {th }}-4^{\text {th }}$ centuries BC as an actual political project. All known projects of oligarchic constitutions in Athens which were destined for real implementations - the constitution of 5,000, that of Thirty, the oligarchic constitutions of Antipater and Demetrius - provided equal access to political rights including all offices for all those who were qualified as citizens according to their property qualification. ${ }^{35}$ Presumably, the same is true for penalties: the fines in the constitution of the 5,000 are at least equal for all members (AP 30.6). ${ }^{36}$

31 Van Wees, 2011, $98 \mathrm{f}$. points out that after 336/335 BC (the reform of ephebic service), the Athenian army had a considerable number of persons who received hoplite equipment through state funding but who would be not have been able to serve as hoplites without this support. He argues also that among those who could equip themselves without state funding there were in addition to the 9,000 men who owned at least enough land to live as independent farmer-hoplites, there were about 4,500 men who owned less property but nevertheless equipped and trained themselves as hoplites at their own expense.

32 In his detailed investigation of Greek oligarchies, Simonton, 2019, 44-45 finds only four unambiguously attested cases of this political order: 1) DC; 2) the Athenian regime after the overthrow of the 400 in 411-410 BC; 3) the constitution of the Malians in Arist. Pol. 4.1297b, 12-16, of unknown date; 4) Herodes Atticus, Peri Politeias 31 (the type of constitution enforced by the Spartans in the subordinate poleis). Of these four, only (2) and possibly (4) are relevant for the $5^{\text {th }}-4^{\text {th }}$ century BC, as Simonton notes: he regards (1) as a political forgery, probably from the time of Demetrius of Phalerum; the reference to the hoplite constitution' in (4), however, is only implicit at best, and the speech itself, which some scholars ascribe to the end of the fifth century BC, belongs in all probability to the time of Herodes (see Russell, 1983, 111). Gehrke, 1985, 13 f., 106-109, 146 f. and after him Blösel, 2021, 184 assign the hoplite constitution to many Greek poleis in the $5^{\text {th }}-4^{\text {th }}$ centuries $\mathrm{BC}$, but the cited evidence does not support this claim (it refers to moderate oligarchies with unclear census requirements or even to radical oligarchies like that in Megara as established by Brasidas in $424 \mathrm{BC}$ ).

${ }^{33}$ For a radical rejection of Aristotle's view see Simonton, 2019, 41-54 with literature; in favor of the view that Athenian zeugitai were in Solon's time 'a broad group of middling peasants' see Valdés Guia, Gallego, 2010, 257-281.

34 Busolt - (Swoboda), I, 1920, 55 noticed the presence of the census' gradation of penalties in the DC in contrast to the constitution of the 5,000, but, apparently, he did not find this important for the question of DC's origin.

35 Van Wees, 2011, 96 f., however, pointing to the awkward wording in Diod. $18.74 .3 \tau$ ?

36 The penalties for not attending the council and the assembly are assigned in the constitution of Plato's Laws only to the representatives of two highest property classes, those of the two lowest are relieved (on other provisions which make obligatory the participation in procedures of election, etc. for the higher class- 
The gradation of census requirements is not attested for the other oligarchic regimes which existed in the $5^{\text {th }}-4^{\text {th }}$ BC. ${ }^{37}$ It is known only in theoretical projects of that time which had a distinctively retrograde character: the constitution of Plato's Laws (764 a 3-6; 765 c 4-5) envisages the ascending census demands for offices in relation to their significance. This is criticized by Aristotle as an oligarchic feature of this constitution (Pol. II 6. 1266 a 12-14); nevertheless, he himself recommends the assignment of offices according to different property ratings both for a moderate democracy (VI 4.1319 a 30-32) and a moderate oligarchy (VI 6. 1320 b 22-25), ${ }^{38}$ but without visible analogies in contemporary reality. ${ }^{39}$

On the contrary, the 'hierarchical' census of DC is entirely in its place in the pre-Solonian age. Solon's constitution, which clearly presents an important step towards democracy both according to Aristotle and the traditional Athenian view, opens the offices (according to AP 7.3) only to the members of the first three classes; within them there is a census hierarchy in regard to the significance of an office, similar to DC. ${ }^{40}$ It is quite possible that just this feature of Solon's constitution inspired the similar proposals of both Plato in the Laws and Aristotle in his recommendations of 'moderating' oligarchies and democracies. At the same time, there is no reason to assimilate DC to Aristotle's ideal of the second-best constitution, or polity, which he located in the past as an intermediary between earlier oligarchy and later democracy in addition to recommending its presence as an ideal of moderate state order based on the prevalence of middle propertied class. In the treatment of it he never mentions any additional census restrictions beyond the basic one, the capacity to equip oneself with hoplite armour, and it appears in this respect as more democratic than DC and even the Solonian constitution. ${ }^{41}$ To resume, DC differs from the oligarchic constitutions of the $5^{\text {th }}-4^{\text {th }} \mathrm{BC}$ which were implemented in Athens or were destined for implementation; it does not appear either to be a reflection of theoretical preferences of Aristotle or some members of his school (the hoplite polity); nor does it correspond exactly to Aristotle's historical scheme of the development from oligarchy via hoplite polity to democracy - DC would not be a polity in Aristotle's eyes but rather a

es, see Schöpsdau, II, 2003, 357-358). On the oligarchic character of this measure, see Rhodes, 1981/1993, 117 who cites the relevant passages from Aristotle's Politics.

37 See Simonton, 2017, 38-39: 'It seems that in most oligarchies... a single fixed timèma admitted one to the most authoritative offices'; he finds that only DC and the constitution of Solon are exceptions from this general rule.

38 See Robinson, 1997, 38 on Aristotle's approval of constitutions with moderate property qualifications.

39 Schütrumpf, Gehrke, III, 649 (ad Pol. VI. 6. 1320 b 23) rightly notice that none of the types of oligarchy treated by Aristotle in Pol. IV 5-6, viz. the actual existing constitutions, use the different property qualifications for access to offices (the same is of course true for democracies).

40 The reading $\mu \varepsilon \gamma \dot{\alpha} \lambda a c$ is unclear (see the discussion by Rhodes, 1981/1993, 138 f.); the meaning of this awkward sentence seems to be that the lower offices were open to all members of three classes without qualification, but the higher were reserved in due proportion to those who corresponded to certain property qualifications, viz. a part of zeugitai had no access to them.

${ }^{41}$ It is not true that Aristotle recommends the double qualification for his hoplite constitution (polity), as Schütrumpf, Gehrke, III, 649 (ad Pol. VI. 6. 1320 b 23) claim (with reference to the IV 9. 1294 b 3ff). For the polity, he proposes a moderate property qualification for membership in the assembly, and no additional qualifications at all for those who would be elected to magistrates, thus one equal qualification for all enfranchised. 
stage on the way to it. ${ }^{42}$ In view of all this, DC looks like a (pseudo-) historical reconstruction rather than a product of doctrinal thinking, irrelevant if a theoretical or political one.

Further consider the figures of property qualification for the highest offices: 10 minas $(=1 / 6$ talents $)$ of an unencumbered property for archons and treasurers and 100 minas $\left(=1 \frac{2}{3}\right.$ talents $)$ of an unencumbered property for generals and hipparchs. ${ }^{43}$

Rhodes, 1981/1993, 113 finds the following suspicious: 1) the assessing of wealth in money at this stage, whereas the later Solon's reform enforces the assession of wealth in natural products; 2) a higher qualification for generals and hipparchs than for archons and treasures; as he notices, this 'at any rate in the relative standing of archons and generals reflects the political realities of the late fifth rather than the late seventh century. Although this might serve as an argument against historical reliability of DC for us, both features do not contradict the view of Draco's age that was typical for the fourth century. Plutarch in the passage which at least partially goes back to AP (Thes. 25.3), ascribes to Theseus the introduction of the 'Bull'-coins. Athenian historians did not doubt the existence of money assessing in Solon's time (see further) and presumably Draco's. The census qualifications, as Rhodes himself admits, do not make sense for the fourth century; these are thus rather invented to fit the realities of Draco's age than to serve as recommendations for the present time.

The higher position of generals and hipparchs in comparison with archons and treasurers, according the DC, evokes many questions; but the provision again differs from the democratic constitution of the $4^{\text {th }} \mathrm{BC}$, when there were no property qualifications for military offices (nor do we know about such qualifications in earlier times), and it is astonishing that a representative of the 'oligarchs' would propose such qualifications for leading military positions instead of abilities to occupy them. For this reason, although these provisions may well be unreliable historically, it is useful to ask what meaning they had for Athenian historians rather than treating them as a piece of political propaganda.

First of all, it is a question of whether our text is sound. There were numerous attempts to correct 10 minas of archons and treasurers into 100, 200 or 300, to make their qualification equal or even higher than that of generals and hipparchs. ${ }^{44}$ However, the special provision made on account of generals and hipparchs, but not archons and treasurers - the former should be bailed by members of the same property class - implies that the former belong to the higher class rather than the latter. ${ }^{45}$ As for their property qualification, it is significant that the guarantors for ex-generals and ex-hipparchs should

42 Solon's constitution would be in some respects less, and in some respects more, democratic than the egalitarian hoplite state; thus it does not appear that Aristotle found a precise analogy to polity in Athenian constitutional development, and one may suppose that polity was for him an ideal type rather than an exact description of a constitutional order.

${ }_{43}$ Cf. already Headlam, 1891, 167.

44 Chambers, 1990, 156 rejects these attempts as useless, 'denn die Bezeichnung des Besitzes der Bewerber als "frei“ setzt ein Verpfändungssystem voraus, das um 620 unwahrscheinlich ist.' However, the provision of an unencumbered property, even if it is anachronistic does not hinder the attempts of emendations which purport to make the text more logical. As for the historicity, it may involve non-mortgaged land and other immovable property estimated in a monetary equivalent: it may be an anachronism for us, but it corresponds to the view of the $A P$ about the economic conditions of that time.

45 The difficult sentence at 2.2 was variously interpreted and emended; grammatically the most plausible is the interpretation of Partsch, 1909, 54, endorsed by Busolt - (Swoboda), I, 1920, 54 n. 3; Fuks, 1953,

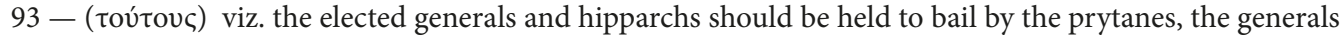
and the hipparchs from the previous year until the accounts of the new officials had been audited, accepting four men as guarantors for each man of the same financial class as the generals and hipparchs. 
be people from the same property class, as the generals and the hipparchs, and, since it is not said that it is a minimal requirement, it follows that they can be elected from the highest class only, viz. from the pentakosiomedimnoi. But what about archons and treasurers? It would be highly improbable if the treasurers were elected from a lower class than the pentakosiomedimnoi, since even in the $4^{\text {th }} \mathrm{BC}$ this requirement remained in force, at least formally (AP 8.1), and it is thus necessary to infer that the archons in DC belong to the same highest class. ${ }^{46}$ But does it mean that one should emend the text in order to make their property qualification equal or higher than that of generals and the hipparchs? If it were the case, it would be sufficient to make them all members of the pentakosiomedimnoi. The special property qualifications must have logic, and logic for both categories of offices, or otherwise one of them could be qualified as pentakosiomedimnoi. These special qualifications imply special demands beyond their class qualification as pentakosiomedimnoi: ${ }^{47}$ the unencumbered property of 10 minas for the archons and the treasurers, 100 for the generals and the hipparchs plus a lawful marriage and children (sons) older than 10 years. Should we emend 10 in the first category? I think that the figures make sense as they stand: one person can be only once an archon, but he can be elected many times as general or hipparch; thus, if it is necessary to have more candidates for archons than for generals and hipparchs, the qualifications for the former should be lower than for the latter. The higher qualifications for the generals and hipparchs may also envisage that they should bear military costs in extraordinary cases.

The situation which results from these provisions is unusual but acceptable. Of course, normally the personal qualities for generals should be more important than property qualifications. But the purpose of the oligarchic constitution is to reserve the highest military command for members of the noblest and wealthiest families; it is expected that they would contribute a sufficient number of able candidates who could be reelected without restrictions.

Does this mean that the offices of generals and hipparchs in DC are more important than those of archons, taken that the figures of property qualification are sound? To an extent it does, since no matter what the reasons were for this provision, the result would have been the increase of influence of the small circle of those who are eligible for the highest military offices. But it was not the purpose of the author of DC to consider the eventual effects of this constitution, which was short-lived. As it stands, the higher property qualifications for the generals and hipparchs hardly signal a loss of significance of the archon position, granted that, after their service, the latter became members of the Areopagus (while the generals and hipparchs did not); and the Areopagus, although having lost a part of its functions in DC, still remains very important as the 'guardian' of laws, the supreme observer of the officials and the highest appellative court (3.4). Rather, we can suppose

46 This is assumed by Staveley, 1972, 239 n. 49 who also believes (p. 33) that under Solon the archonship was limited to the pentakosiomedimnoi. Staveley refers to Demetr. Phaler. 228 F $43=$ Plut. Aristid. 1 (the archonship was still open to the first class only as late as 489/8); Rhodes, 1981/1993, 148 may well be right in his doubts that pentakosiomedimnoi would provide the sufficient number of archons, but it is sufficient that Demetrius of Phalerum believed that it did, and this could easily be the view of the author of DC.

47 The standard surmise is that the property qualifications based on total property in DC are alternative to Solon's later qualifications based on natural year income. But the fines for absenting in the boule are appointed below in accordance with the 'Solonian' classes which are presumed to exist at this time; since citizens are qualified as those who can equip themselves as hoplites, the latter category may simply be a shorter designation for the first three 'Solonian' classes. 
that it was a supposed measure by the legislators who wanted to balance the concentration of military power in the hands of a small number of the wealthiest families (which in all probability controlled the state previously) by granting access to the highest offices to a wider circle of the pentakosiomedimnoi. Cf. AP 3.3 on Codrides who deposed hereditary regal power in exchange for re-distribution of the prerogatives from the basileus to the newly created eponymous archon, presumably together with acquiring the privileged rights of occupying the latter office.

The law on the bail and guarantors for the military officials is beyond any doubt an anachronistic one. ${ }^{48}$ Two points are interesting: first, it imitates a real legal provision and thus creates an impression of a real law; second, it cannot be implemented in the $5^{\text {th }}$ or $4^{\text {th }}$ century because the designation of military officials from a very narrow circle of the richest was not a goal of any group of oligarchs. It is much more plausible that this provision was invented to accommodate the historical situation of the $7^{\text {th }}$ century or, more specifically, the imagined conditions of the order created by Draco. It reflects the imaginary situation in which the state undertakes strict measures of control over the highest military offices to prevent their occupation by people beyond the narrow circle of the wealthiest families.

The figures of property qualifications for offices are surprisingly low in terms of the $4^{\text {th }} \mathrm{BC}$, as Rhodes notices. The qualification of liturgy was in the $4^{\text {th }} \mathrm{BC}$ approximately four talents, and there were about 1,200 citizens liable to the trierarchy in the mid-fourth $\mathrm{BC}$, or four percent of the entire citizen body. ${ }^{49} \mathrm{Of}$ course it is not plausible that the author of a constitutional proposal in the $4^{\text {th }} \mathrm{BC}$ would have made the highest qualifications for officials thrice lower than the qualifications of liturgy. Even if one supposes that the author wanted to make all the highest offices available to people of the class lower than the liturgic one, it is improbable that he would open the office of the treasurer, which even in the democratic constitution of the $4^{\text {th }} \mathrm{BC}$ was available only to pentakosiomedimnoi ( $A P$ $8.1 ; 47.1)$. The figures are thus inappropriate for a real constitutional proposal and superfluous as a fictitious historical precedent for such a proposal. However, they correspond to what one in the $4^{\text {th }}$ century could believe to be property qualifications in the monetary equivalent for an earlier age. Plutarch (Sol. 20.3-4, commenting on the on surprisingly low money fines according to Solon's laws, supposes that this can be explained by scarcity of $\operatorname{coin}^{50}$ at that time. He refers to Solon's law according to which 1 medimn is equal to 1 sheep or 1 drachma; he also cites Demetrius of Phalerum (fr. 147 Wehrli), according to whom the price of an ox was 5 drachmas, and a sheep 1 drachma. It is likely that Demetrius is Plutarch's source for this whole reasoning. ${ }^{51}$ No matter how historically true is

48 See Partsch, 1909, 395; Fuks, 1953, 94.

49 Rhodes, 1981/1993, 113.

50 Plutarch's explanation is in fact, as the following reasoning shows, that the prices in Solon's time were much lower than the present ones, and his statement on the scarcity of coin may serve as an explanation for these low prices (the increasing number of coins results, presumably, in the growth of prices); but at the start he creates the impression that Solon's real purpose was to make the fines heavier by estimating them in coinage, as if it was more difficult to pay with coins than with natural products, which was certainly not the case granted that fines counted in natural products turn out to be equally high.

51 Wehrli, 1968, 77 assigns to Demetrius only part of the sentence, and he thinks that Demetrius' point was not the comparison of old and present prices, but a comment on some of Solon's laws; he finds him involved in contradictions. In fact, the whole reasoning is coherent and may go back to Demetrius: he defends Solon against the accusation of inconsistency, explaining the low figures of fines by high prices, adduces the available evidence from Solon's laws on the relation of money and natural standards. Having noticed that the 
Plutarch's (or Demetrius') explanation, the underlying idea that money estimations in part should have been considerably lower than the present ones, squares neatly with the property qualifications of DC. If the annual production of Solon's pentekasiomednoi amounts to 500 drachms or 5 minas, the total property of 10 minas of Draco's pentekasiomednoi would not be a small figure (granted that the annual bare income is hardly more than $1 / 4$ of the whole production), and only a small number of this class would own property at 100 minas. I take it also as an additional argument against the emendation of 10 into 100, not say 200 or 300 minas - this would make the number of persons eligible for archonship very insignificant. ${ }^{52}$ The fines for not partaking in the session of boule or ekklesia $(3,2,1$ drachmas for members of the three classes) are also rather high, in terms of prices adduced by Plutarch. ${ }^{53}$

The property requirements for access to offices and penalties for non-presence in the council and assembly are given in minas and drachmas, and this carries a suspicion because modern historians are certain that Athens did not have its own coinage even at the time of Solon and some time after him, and money circulation was insignificant in Draco's time as follows from the fact that the census distinctions between classes in Solonian constitution were drawn on the basis of natural income (AP 7.3).$^{54}$ The anachronism of such a sort would not have been, however, obvious to Aristotle or to the author of DC. Aristotle reports without any doubt about Solon's reform of coinage (AP 10), obviously not being aware of the scarcity of money in circulation at that time and the lack of minting in Athens. ${ }^{55}$ Notice also that DC does not describe the basis on which distinctions between property classes were drawn in that time. Monetary distinctions are mentioned only for special cases mentioned above (AP 7.3). There is thus no open contradiction between the two constitutions on monetary matters which would make Aristotle or the author he used suppose anachronisms, or make us infer that DC is an insertion into the main part of $A P$.

The presence of strategoi and hipparchoi, as the officials with the highest census requirements in DC (see further against attempts to emend numbers of requirements for officials), appears to be an anachronism since it is unlikely that at least strategos was the regular office before 501/0 BC, see AP 22.2 (see the discussion by Rhodes 1981/1993, 264).

prices for several sacrificial animals are some times higher than the usual ones, he affirms that even so they are lower in comparison with the present ones.

52 I put aside the complicated question of the existence of money equivalents in Solon's laws. The specialists date the introduction of coinage in Athens to about the mid-sixth century BC; Ste Croix, 2004, 40 believed that the drachma fines, rewards and values were added later, and if Solon had in view not money, but silver measures, he would have spoken 'drachma of silver', not 'drachma', but Kroll, Waggoner, 1984, 332 do not doubt that Solon had in view silver measures ('these drachmas must have been drachma weights of uncoined or bulk silver'). For my purpose, it is only important that Demetrius did not doubt the existence of money standards in Solon's laws. Both Androtion (Plut. Sol. 15.3-4 = 324 F 34) and the AP 10.1 ascribe to Solon the reform of coinage, but their accounts are different; according to Kroll, Waggoner, 1984, 332, it was the reform of weight, not coin denomination, cf. Rhodes, 1981/1993, 168.

${ }^{53}$ According to the relation in Solon's constitution, the fines should be 1, 11/2, 21/2 drachmas; one may speculate that fines tend to punish the higher classes more severely in accordance with oligarchic practice.

${ }^{54}$ Rhodes $1981 / 1993,113$ on 4.2 ; 117 on $4.3 ; 168$ on 10.3; Rhodes admits that uncoined silver could be used as money in the time of Solon (p. 152). Minas and drachmas in DC would then be measures of silver and less anachronistic even from the modern point of view, but it is not my purpose to defend the historicity of its account.

${ }^{55}$ If the ascription of the introduction of 'Bull' coins to Theseus (Plut. Thes. $25.3=A P$ fr. 3 Chambers) goes back to Aristotle, he had even more grounds to believe that money income and money fines were in use in the time of Draco. 
Nevertheless, the view of the AP does not necessarily correspond to ours: it mentions twice Pisistratus as strategos (17.2; 22.3). Of course, the omission of strategoi and taxiarchoi in the list of the highest officials according to the Solonian constitution is suspicious, but Rhodes' well-balanced view that both kinds of commanders existed before 501/0 BC but were not elected on regular basis need not have been the view of Aristotle. He may well have thought that his information on Solonian officials and their census requirements was not exhaustive; it is by no means certain that the point of the AP 22.2 is the institution of the regular office of ten strategoi rather than the new procedure of their election (by vote, one from each tribe).

The existence of the second council, along with that of Areopagus, is not attested elsewhere prior to Solon; scholars suppose that the number of its members, 401, in contrast to Solon's council of 400 and Clisthenes' of 500 (in each case one hundred councillors from each tribe), was invented in light of the uneven number of judges in Athenian courts, which appeared after 403/2 BC. ${ }^{56}$ The suggestion about the impact of later democratic institutions might well have been correct, but it does not explain the function of this provision in DC. The ascription of the council to Draco seems to be an attempt to decrease Solon's fame as the creator of the second council, along with Areopagus. Furthermore, since the members of the council are sorted by lot in DC from the entire citizenry, not from tribes as in Solon's and Cleisthenes' constitutions, the number 401 may be invented purposefully to closely resemble Solon's number without the relation of tribes. The uneven number may also be chosen deliberately, in order to stress the importance of having a majority of votes in the council: the non-attendance of it is punished by fines, thus the plenum can be regarded as desirable. Be as it may, it is important that the oligarchic constitutions of 411 and 404/3 BC did not attempt to change the traditional even number: in the first case, the oligarchs returned to old Solon's council of 400 (now with 40 representatives from each of the ten tribes, AP 31.1); in the second, the oligarchs designated the members of the new council themselves, but preserved the earlier number 500 of the democratic constitution (AP 35.1), presumably also the equal representation of each tribe. ${ }^{57} \mathrm{DC}$ is in this respect appears to be strikingly out of date rather than politically relevant.

Now, let's look how DC appears in the narrative of the AP. The political and economic state of affairs before Solon is presented as entirely oligarchic (2.1-2, cf. 4.5-5.1). DC is offered as having not modified this state of affairs (and in this respect may be regarded as an integral part of the text): it restricts access to the most important offices with the highest property class and does not attempt any economic reform. DC is thus presented as both an unsuccessful attempt of managing social and political conflicts by means of granting political rights to a wider circle of well-to-do citizens and paving the road for Solon's more radical and more successful political reform.

However, the spirit in which DC was forged appears to be entirely different. Its author attempted to present Solon's reforms as less innovative than they would be without $\mathrm{DC}$ as an intermediary and constitutional development more gradual: Draco, not Solon, becomes the author of the division of citizens into four property classes and granting the right to elect officials to the highest three of them, in the place of the earlier monopoly of

${ }^{56}$ Fuks, 1953, 94-95, cf. Rhodes, 1981/1993, 115, 729 who is less certain that the change took place in the fourth century.

57 On retaining tribal representation in the later time, in spite of the changing number of tribes themselves and the total number of counsellors, see Rhodes, 1972/1985, 1. 
the Areopagus in designating officials. Draco also becomes the author of the creation of the Council (boule) of 401, an attempt to abandon another monopoly of the Areopagus that of deliberative council. It introduced a mixed procedure for voting and sortition for electing officials which anticipates that of Solon; the institution of euthynai, the eisanggelia. Little of this resembles a political project that could be actual for the fifth or fourth centuries BC.

Of course, any thoughts on the possible source of this forged constitution can be only tentative. I adduced earlier arguments against the view that DC is an insertion into the $A P$ made later by some redactor of the text; it is more difficult to refute the view that it was added later by Aristotle himself. At least there are no sufficient reasons to think that it was not integrated into the main text, one can only debate whether this integration was successful. On the other hand, we can certainly rule out the possibility that Aristotle compiled DC himself from various sources, as some scholars believe, most recently Poddighe, 2014, 143: in that case we would expect, along with the information he straightforwardly reports as evoking no doubt, also, in cases of more debatable points, references to opinions of his sources; the reasons for his own view, in a more or less probabilistic form; inferences from the lacunose and not always reliable evidence, and some issues left unsettled due to the lack of evidence. Precisely this is his modus operandi in the account of the 'ancient constitution,' which was in force before Draco (AP 3$)^{58}$ and even in the account of Solon's reform ${ }^{59}$ for which he had more material at his disposal than for the 'ancient constitution' (AP 5-12). It is thus next to certain that Aristotle found DC in the form of a unified account which appeared reliable to him just because of its dry, 'business' style. ${ }^{60}$ Stylistically, $\mathrm{DC}$ is in fact very close to the constitutional projects of $411 \mathrm{BC}$ in the AP 30-31 which may derive from real documents. ${ }^{61}$

The provenience of such a forged document can be only guessed and I would not speculate on it. In the fourth century BC, there are many attested cases of falsified documents which were in some instances even inscribed on stones, the decree of Themistocles is probably the best known. ${ }^{62}$ Forged documents are of very different character and

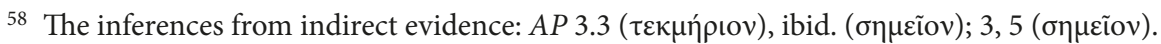

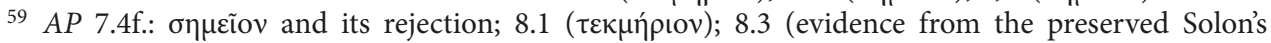
laws); citation of Solon's poems as testimony for his middle position between the nobility and the people (12.1-3) and for his seisachtheia (8.4).

60 Cf. Dovatour, 1965, 299, who contrasts the accounts of DC as well as both constitutions of 411 BC in which Aristotle follows the style of his documentary source with the apparent additions of Aristotle himself on varying opinions, his own arguments in favour of one of them, etc., in his accounts of the 'ancient constitution' and that of Solon. Already Wilamowitz believed that Aristotle drew on a documentary source which was reliable in his view. Nevertheless, he noticed the lack of any traces of archaic style in the account and created a complicated theory that the text Aristotle used was compiled in the time about $411 \mathrm{BC}$ from Draco's inscribed laws (he rightly excluded that Draco could produce the text of the constitution overall), see Wilamowitz, 1893, I, 77. This however begs the question why no traces of archaisms remained in this alleged compilation of old laws Aristotle used. Granted that the content of DC is not genuine, its documentary style implies a source which imitated the document.

61 The ultimate provenience of the oligarchic constitutions of $411 \mathrm{BC}$ is debatable (see (Gomme)Andrewes, V, 1981, 246-251; Rhodes, 1981/1993, 387-389; Heftner, 2001, 177-203), but the documentary character of it, either of epigraphic or 'paper' character, is very probable. It is of course possible that Aristotle could reproduce scattered information on oligarchs' constitutional plans imitating a documentary style, but the precision of the accounts and lack of any inferential and probabilistic statements rule out this possibility like in the case of DC. That Aristotle obtained both constitutional drafts via some intermediary source of literary character, for instance Androtion's Atthis, is possible but not certain.

62 See Habicht, 1961, and further Robertson 1978; Davies 1996; Lambert 2018, 88. 
obviously served various purposes. Also their provenience, historiography or rhetoric is debatable. In the case of DC, a historiographic source is more probable, since a detailed account of the constitution is difficult to imagine in the rhetorical context. The lack of political actuality speaks in favor of pseudo-historical 'reconstruction,' which purported to fill gaps in the tradition of Athenian constitutional antiquities rather than attempting to glorify the past in the interest of some party or Athens on the whole. The appearance of a historical document yields a possibility that the author of DC wanted to deceive his readers, viz. that we have to deal with a real falsification.

Schematic detalisation of this kind also occurs in other parts of the AP. The most striking example is a passage preserved by secondary tradition from the lost beginning of the treatise (fr. 2 Chambers): according to it, the Athenians in legendary times were divided into two classes, the georgoi and demiourgoi; and simultaneously into four tribes, phylai, each divided into three parts called phratriai or trittyes; each phratria divided into thirty gene, and each genos consisting of thirty gennetai. The number of tribes corresponded to four seasons, of phratries to twelve months, and of gene to 360 days. ${ }^{63}$

This over-schematic political order is of course not a result of gradual development but the creation of some person. According to a plausible suggestion by Wade-Gery, ${ }^{64}$ Aristotle ascribed this order to Ion: in the account of the changes of the Athenian constitution, Aristotle credits Ion who settled in Athens alongside his comrades with the creation of four Ionian tribes (AP 41.2). It is thus probable that the whole system of tribes, phratries and clans was his creation, and that it was an artificial system which included both autochthon inhabitants of Attica and the new settlers. ${ }^{65}$ The ascription of the tribal order to Ion was traditional, but the schema of twelve phratries, thirty clans etc., with its 'implausible neatness' (Rhodes, 1981/1993, 68), is extraordinary.

This similarity points to DC as the invention of an antiquarian. Of course, there could be some political sympathies and prejudices in his invention; however, its main purpose is not directly political, as I argued, but rather a desire to fill the gap in constitutional history between Solon and the pre-Solonian state order. The use of this material provides no credit to Aristotle, but his mistake can be explained.

63 The fragment is attested by Lex. Patm. 152 s. v. $\gamma \varepsilon v v \tilde{\eta} \tau \alpha$ । (BCH 1, 1877), and Schol. in [Plat.] Axioch. $371 \mathrm{~d}$ (p. 413 Greene). The entry in the Lex. Patm. consists of the preamble and the citation from Aristotle; the Scholiast cites Aristotle. The preamble and the citation give similar information, but there are some differences. Only the preamble mentions the division into georgoi and demiourgoi but this seems to be a part of Aristotle's genuine text as according to the Scholiast on the Axiochus; the preamble, but neither of citations, mentions the priesthoods allotted to certain gene, such as Eumolpidai, Kerykes etc, and this universally known detail might be in fact an addition to Aristotle. On the contrary, the calendar simile appears only in the citation. The text of the preamble is very close to the Harpocr. $\Gamma 5$ ( $\gamma \varepsilon v v \tilde{\eta} \tau a)$; only thirty men constituting each genos are not mentioned. The entry in Harpocrtion is attributed by Jacoby to Philochorus (FGrH 328 F 35 b) but this attribution is not certain; it is based on Philoch. Fr. 35 a (from Suda and Photius)

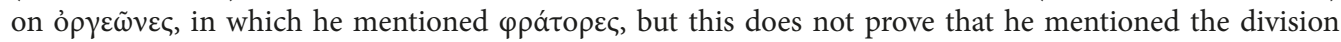
into tribes etc. Even if it were the case, Harpocration's entry is close to the preamble from the Lex. Patm. but not to the text cited as Aristotelian. Jacoby (FGrH 3 b, Suppl. 1, 322. 19) thinks that Aristotle possibly did not mention $\gamma \varepsilon v v \tilde{\eta} \tau \alpha$, and he notices that $\gamma \varepsilon$ v́vৎ is for Aristotle an artificial division, not the descendants from one ancestor (compare Suda s. v. $\gamma \varepsilon v v \tilde{\eta} \tau \alpha$ - the notice that $\gamma \varepsilon$ vo precedes the text which is very close to the Aristotelian fragment)

64 Wade-Gery, 1931, 2-6, endorsed by Rhodes 1981/1993, 67, and Lambert, 1993, 88.

${ }^{65}$ I argued in Verlinsky 2017 that although the innovations under Ion were included in the list of metabolai, this first change of the state order was not for Aristotle a constitutional one, viz. it was not a change in direction of democracy or oligarchy. 


\section{References}

Blösel W. Die Hopliten in den beiden oligarchischen Umstürzen in Athen und eine mögliche Neuordnung der Zensusklassen am Ende des 5. Jahrhunderts v. Chr. in: Riess W. (Hrsg.) Colloquia Attica. Bd 2. Neuere Forschungen zu Athen im 5. Jahrhundert v. Chr. Stuttgart, Steiner, 2021, 181-196.

Busolt G. Griechische Geschichte bis zur Schlacht bei Chaeroneia II $^{2}$. Gotha 1895.

Busolt G., Swoboda H. Griechische Staatskunde I-II. München, Beck, 1920-1926.

Carey C. In search of Drakon. The Cambridge Classical Journal 2013, 59, 29-51.

Cataudella M. R. Atene fra il VII e il VI secolo: aspetti economici e sociali dell'Attica arcaica. Catania, Universita di Catania, Facoltà di Lettere e Filosofia, 1966.

Cecchin S. A. Patrios politeia: un tentativo propagandistico durante la guerra del Peloponneso. Torino, Paravia, 1969.

Chambers M.H. (tr., comm.), Aristoteles Werke 10/1. Staat der Athener. Berlin, Akademie Verlag, 1990.

Chambers M. H. Georg Busolt: His Career in His Letters. Leiden, Brill, 1990 [Chambers 1990a]

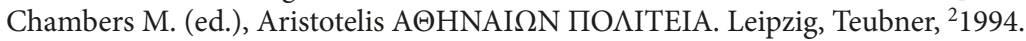

Cloché P. Remarques sur la prétendue Constitution de Dracon. REA 1940, 42, 64-73.

Davies J.K. Documents and 'documents' in fourth-century historiography in: P.Carlier (ed.) Le IVe siècle avant Jésus-Christ: approches historiographiques, Actes du colloque international de Nancy des 28-30 septembre 1994. Nancy, ADRA - Paris, De Boccard, 1996, 29-39.

Develin R. The Constitution of Drakon. Athenaeum 1984, 62, 295-307.

Dovatour A. I. The Politics and the Politeiai of Aristotle. Moscow - Leningrad, Nauka Publ., 1965 (in Russian).

Ferguson W. S. The Oligarchic Movement in Athens in: Cambridge Ancient History V, 1927, 312-347.

Figueira Th. The Strange Death of Draco on Aegina, in: R. Rosen, J.Farrell (eds), Nomodeiktes: Studies in Honor of Martin Ostwald. Ann Arbor, University of Michigan Press, 1992, 287-304.

Fuks A. The Ancestral Constitution: Four Studies in Athenian Party Politics at the End of the Fifth Century B. C. London, Routledge \& Kegan Paul, 1953.

Gagarin M. Writing Greek Law. Cambridge, Cambridge University Press, 2008.

Gehrke, Hans-Joachim, Stasis: Untersuchungen zu den inneren Kriegen in den griechischen Staaten des 5. und 4. Jahrhunderts v. Chr. München, Beck, 1985.

Gomme A. W. The Population of Athens. Oxford, Basil Blackwell, 1933.

Gomme A. W., Andrewes A. A Historical Commentary on Thucydides. Vol. V. Book VIII. Oxford, Clarendon Press, 1981.

Habicht C. Falsche Urkunden zur Geschichte Athens im Zeitalter der Perserkrieg. Hermes 1961, 89, 1-35.

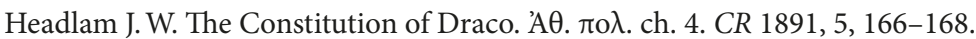

Heftner H. Der oligarchische Umsturz des Jahres 411 v. Chr. und die Herrschaft der Vierhundert in Athen: quellenkritische und historische Untersuchungen. Frankfurt a. M., Lang, 2001.

Heftner H. Oligarchen, Mesoi, Autokraten: Bemerkungen zur antidemokratischen Bewegung des späten 5. Jh. v. Chr. in Athen. Chiron 2003, 33, 1-41.

Heftner H. Hopliten und Hippeis unter dem Regime der 30 Tyrannen. Tyche 2011, 26, 141-164.

Hölkeskamp K.-J. Schiedsrichter, Gesetzgeber und Gesetzgebung im archaichen Griechenland. Stuttgart, Steiner, 1999.

Hurni F. Comment les Cinq-Mille furent-ils sélectionnés en 411? Museum Helveticum 1991, 48, 220-227.

Jacoby F. Atthis: The Local Chronicles of Ancient Athens. Oxford, Clarendon Press, 1949.

Kroll J.H., Waggoner N. M. Dating the Earliest Coins of Athens, Corinth and Aegina. American Journal of Archaeology 1984, 88, 325-340.

Lambert S. D. The Phratries of Attica. Ann Arbor, University of Michigan Press, 1993.

Lambert S. D. Inscribed Athenian Laws and Decrees in the Age of Demosthenes: Historical Essays. Leiden, Brill, 2018.

Leão D. F., Rhodes P. J. The Laws of Solon: A New Edition with Introduction, Translation and Commentary. London; New York, Tauris, 2015.

Ledl A. Studien zur älteren athenischen Verfassungsgeschichte. Heidelberg, Winter, 1914.

Meyer Ed. Forschungen zur alten Geschichte I. Halle, Niemeyer, 1892.

Németh G. Kritias und die Dreissig Tyrannen: Untersuchungen zur Politik und Prosopographie der Führungselite in Athen 404/403 v. Chr. Stuttgart, Steiner, 2006.

Partsch, Josef, Griechisches Bürgschaftsrecht. 1. Teil. Das Recht des altgriechischen Gemeindestaats. Leipzig, Teubner, 1909. 
Poddighe E. Nel segno di Antipatro: Leclissi della democrazia ateniese dal 323/2 al 319/8 a.C. Roma, Carocci, 2002.

Poddighe E. Aristotele, Atene e le metamorfosi dell'idea democratica. Da Solone a Pericle (594-451 a.C.). Roma, Carocci, 2014.

Rhodes P. J. The Athenian Boule. Oxford, Clarendon Press, 1972, reissued with addenda 1985.

Rhodes P. J. A Commentary on the Aristotelian Athenaion Politeia. Oxford, Clarendon Press, 1981, reissued with addenda 1993.

Rhodes P.J. The Reforms and Laws of Solon: an Optimistic View in: J.H.Blok, A.Lardinois (ed.) Solon of Athens: New Historical and Philological Approaches. Leiden, Brill, 2006.

Rhodes P. J. The Athenian Constitution Written in the School of Aristotle. With an introduction, translation and notes. Liverpool, Liverpool University Press, 2017.

Robertson N. False Documents at Athens: Fifth-Century History and Fourth-Century Publicists. Historical Reflections / Réflexions Historiques. 1976, 3, 3-25.

Ruschenbusch E. Patrios Politeia: Theseus, Drakon, Solon und Kleisthenes in Publizistik und Geschichtschreibung des 5. und 4. Jahrhunderts v. Chr. Historia 1958, 1, 398-424.

Ruschenbusch E. $\mathrm{O} \Lambda \mathrm{ONO} \Sigma$ NOMOI: die Fragmente des Solonischen Gesetzeswerkes mit einer Text- und Überlieferungsgeschichte. Wiesbaden, Steiner, 1966.

Russell D. A. Greek Declamation. Cambridge, Cambridge University Press, 1983.

Rizzo F. P. La costituzione di Draconte nel c. IV dell'Athenaion Politeia di Aristotele. Memorie dell'Istituto Lombardo di Scienze e Lettere. Classe di scienze morali e storiche 1963, 27, 271-308.

Robinson E. The First Democracies: Early Popular Government outside Athens. Stuttgart, Steiner, 1997.

Sancho Rocher, Stasis y krasis en Tucidides (8.97.1-2). Habis 1994, 25, 41-69.

Schöpsdau K. (tr., comm.), Platon. Nomoi (Gesetze). Übersetzung und Kommentar. Vol. I-II. Göttingen, Vandenhoeck \& Ruprecht, 1994-2011.

Schütrumpf E., Gehrke H.J. (tr., comm.), Aristoteles Werke. 9. 3. Politik, Buch IV-VI. Berlin, Akademie Verlag, 1996.

Seeck O. Quellenstudien zu des Aristoteles' Verfassungsgeschichte Athens. Klio 1904, 4, 164-181, 270-326.

Sickinger J. P. Public Records and Archives in Classical Athens. Chapel Hill - London, University of North Carolina Press, 1999.

Simonton M. Classical Greek Oligarchy: A Political History. Princeton, Princeton University Press, 2017.

Staveley E. S. Greek and Roman Voting and Elections. Ithaca, New York, Cornell University Press, 1972.

Ste Croix G. E. M. de, Athenian Democratic Origins: and Other Essays. Oxford, Clarendon Press, 2004.

Stroud R.S. Drakon's Law on Homicide. University of California Publications: Classical Studies 3. Berkeley, University of California Press, 1968.

Sundwall, De institutis reipublicae Atheniensium post Aristotelis aetatem commutatis, Acta Scientiarum Fennicae, 1907, XXXIV, 4, 22.

Valdés Guia M., Gallego J., Zeugitai and Solonian Census-Classes. Historia. 2010, 59, 257-281.

Van Wees H. Demetrius and Draco: Athens' Property Classes and Population in and before 317 BC. JHS 2011, 131, 95-114.

Verlinsky A. Draco's Constitution in the Athenaion Politeia 4: Is It an Interpolation or an Author's Later Addition? Hyperboreus, 2017, 23, 142-173.

Wade-Gery H. Eupatridai, Archons, and Areopagus. CQ 1931, 25, 1-11; 77-89.

Wallace R. W. The Areopagos Council: To 307 B. C. Baltimore - London, John Hopkins UP, 1989.

Wallace R.W. Aristotelian politeiai and Athenaion Politeia 4, in: R. Rosen, J.Farrell (eds), Nomodeiktes: Studies in Honor of Martin Ostwald. Ann Arbor, University of Michigan Press, 1992, 269-286.

Wehrli F. Die Schule des Aristoteles. Bd. 4. Demetrios von Phaleron. 2. Aufl. Basel, Schwabe, 1968.

Wilamowitz-Moellendorff U.von. Aristoteles und Athen I-II. Berlin, Weidmann, 1893.

Received: September 11, 2021

Accepted: October 22, 2021 